Saudi Journal of Medical and Pharmaceutical Sciences

Abbreviated Key Title: Saudi J Med Pharm Sci ISSN 2413-4929 (Print) |ISSN 2413-4910 (Online) Scholars Middle East Publishers, Dubai, United Arab Emirates Journal homepage: https://saudijournals.com/sjmps

Original Research Article

\title{
Knowledge of Tradi-Practitioners on Hemorrhoidal Disease and Anti- Hemmoroidal Plants in the Southeast Region of Cameroon: Pharmacology and Preliminary Phytochemistry
}

Patrice Brice Mvogo Ottou ${ }^{1 *}$, Jacques Bruno Ngotta Biyon ${ }^{1}$, Seraphine Ebenye Mokake ${ }^{1}$, Parfait Olivier Bissemb ${ }^{1}$, Lazare Roland Owono Fouda ${ }^{3}$, Téclaire Ngouondjou Foze ${ }^{1}$, Gisèle Margueritte Etame Loe ${ }^{2}$, Richard Priso ${ }^{1}$, Siegfried Didier Dibong ${ }^{1,2}$

${ }^{1}$ Laboratory of Biology and Physiology of Plant Organisms, Department of Botany, P.O. Box 24 157, University of Douala Cameroon

${ }^{2}$ Pharmaceutical Science Laboratory, Department of Pharmaceutical Sciences, Faculty of Medicine and Pharmaceutical Sciences, P.O. Box 2701, University of Douala Cameroon

${ }^{3}$ Cite Verte Health District, P.O Box 13889, Ministry of Public Health, Yaounde

DOI: $10.36348 /$ sjmps.2020.v06i04.001

| Received: 01.03.2020 | Accepted: 09.03.2020 | Published: 07.04.2020

*Corresponding author: Patrice Brice Mvogo Ottou

\section{Abstract}

The contribution of phytotherapy to solving hemorrhoidal problems is incontestable because of the richness of plants as secondary metabolites. However, it is important to know the pathophysiology of this disease in order to give effective drug recipes for its treatment. In order to understand the different aspects of hemorrhoidal diseases and to identify plants used for its treatment, an ethnobotanical survey was carried out among trade-practitioners of the Southeastern region of Cameroon. During data collection, information was collected on hemorroidal diseases and plants used for its treatment. The relative importance (RI) of the plants was indicated and the phytochemical screening of the plants of interest was performed. Patients who approached trade-practitioners to seek treatment for hemorrhoids were mostly men $(66 \%)$ between the ages of 35-60 years. Rectal bleeding and glair (30\%) was the most obvious symptom. The ethnobotanical survey identified 48 plants including 35 woody and 13 herbaceous plants used by trade-practitioners to treat hemorrhoids. Piper umbellatum, Antrocaryon klaineanum, Trilepisium madagascariense, Myrianthus arboreus, Irvingia gabonensis, Morinda lucida, Spathodea campanulata, Alchornea cordifolia, Mangifera indica and Baillonella toxisperma were the most used species. These plants were rich in many bioactive compounds amongst which phenolic compounds, coumarines and triterpenes were the most represented.

Keywords: Bioactive compounds, Hemorrhoids, Medicinal plants, and Tradi-practitioners.

Copyright @ 2020: This is an open-access article distributed under the terms of the Creative Commons Attribution license which permits unrestricted use, distribution, and reproduction in any medium for non-commercial use (NonCommercial, or CC-BY-NC) provided the original author and source are credited.

\section{INTRODUCTION}

Since time immemorial, humans have looked to nature for ways to improve their living conditions and increase their chances of survival. Plants contribute to food security and primary health care to nearly $80 \%$ of the population in developing countries $[1,2]$. In the field of pharmacology, traditional herbal knowledge has become a recognized tool in the search for new molecules to produce more effective and less toxic drugs and pharmaceuticals. In case of failure of preventive medicine and the dysfunction of hospital medicine, the World Health Organization recommends that trade-practitioners become more involved in primary health care strategies.

Hemorrhoids are very often confused with many other pathologies of the anal margin including abscesses, tumors, skin tags and fissures [3] Pathogenicity of hemorrhoidal disease is very complex. There is a dilated vein of the mucous membrane of the anus and rectum that is the most common pathology of the terminal intestine [4-6]. This disease may be caused by a variety of factors, including weakness of the venous structures, constipation or some other pathologic increase in intra-abdominal pressure, and dysfunction of the arteriovenous shunts with excessive arterial. The exact prevalence of symptomatic hemorrhoids is very difficult to establish, because many sufferers do not seek for proper care (hemorrhoidal disease is considered by the opinion to be a "shameful" disease) or rely on over-the-counter remedies, whereas others attribute other anorectal symptoms as being a result of hemorrhoids $[7,8]$. 
Although, epidemiological data are available, especially in developed countries; current conventional treatments of hemorrhoids include pharmacological therapies and surgery [9-12]. Pharmacological therapies include drugs like Calcium dobesilate as a venotonic or phlebotonic agent, topical agents containing anesthetics and corticosteroids and physical therapies such as ice and sit baths $[13,14]$. Reason why, drugs used to solve hemorrhoid problems are anti-bleeding, venotonic, nonsteroidal anti-inflammatory, and antinociceptive [15]. These are characterized by a high content of various bioactive molecules especially phenolic compounds $[16,17]$.

Plants possess secondary metabolites and are sources of new molecules whose interest leads to the production of more effective drugs and less toxic than the convalescent drugs. Forest dwellers and communities living nearby and dependent on plants for their livelihood, have very rich empirical knowledge about Non Timber Forest Products (NTFPs) [18, 19]. These natives administer to patient's medicinal preparations generally made of vegetable drugs to which animal organs and mineral and / or alcoholic substances are sometimes associated.
In Cameroon, few studies have focused on the knowledge, especially on the clinical and epidemiological aspects of hemorrhoidal disease. Moreover, despite the advent of generic drugs, these remain ineffective and very inaccessible to the economically deprived populations. These populations continue to turn to nature for essential herbal remedies to provide primary health care. In addition, despite Cameroon's investigations of medicinal plants, many part of Cameroon have not been subject to ethnobotanical surveys. These natives, specialists in traditional medicine, are increasingly refractory and skeptical [20]. Thus, even if they agree to respond to ethnobotanical interviews, their true knowledge and secrets are reserved; indicating an additional problem which is the reliability of the information collected from tradi-practitioners [20]. Thus the purpose of this ethnobotanical study was to have knowledge of hemorrhoidal diseases and to identify the recipes used for its treatment.

\section{MATERIALS AND METHODS Description of the Study Area}

Cameroon is a central African country whose triangular shape covers an area of $475000 \mathrm{~km}^{2}$. It extends from $01^{\circ} 38$ 'to $13^{\circ} 00^{\prime}$ North Latitude and $08^{\circ}$ 35 'to $16^{\circ} 08^{\prime}$ East Longitude.

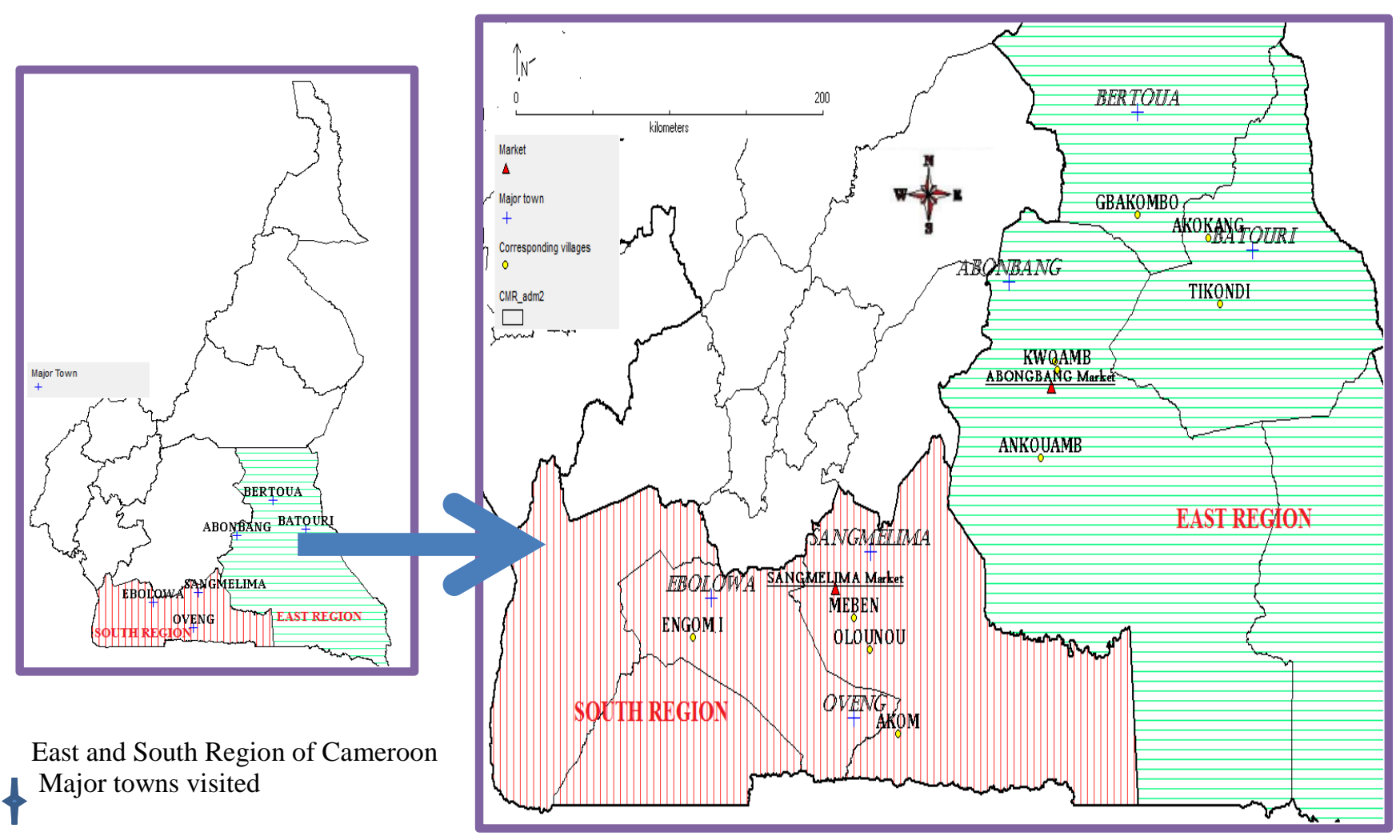

Fig-1: Indicating the different study sites 
The East Region is the largest in Cameroon. It is located between Latitudes $1^{\circ} 00^{\prime} 0-3^{\circ} 49^{\prime} 59 \mathrm{~N}$ and Longitude $14^{\circ} 10^{\prime} 0-16^{\circ} 00^{\prime} 0 \mathrm{E}$. It is bounded in the north by Adamaoua, in the east by the RCA, in the south by the Republic of Congo and in the west by the South and Centre regions of Cameroon. Its population, although almost doubling between the censuses of 1976 and 2005, represents 777755 inhabitants, $4.4 \%$ of the total population of Cameroon. It is the least densely populated region with 7.1 inhabitants per $\mathrm{km}^{2}$. This Region is inhabited, among other tribes, by the pygmies, first inhabitants of the Region who are engage in gathering, collecting and hunting. Also known as the region of the rising sun, the East is an ecological area dominated by tall trees. There are nearly 1,500 plant species, some of which are fully or partially protected, as well as more than 500 animal species that mainly inhabit the Dja Reserve, declared World Heritage of Humanity.

Located in the southern end of the country, the South Region is bordered in the north-west by the Littoral Region, in the north by the Centre Region and in the east by the East Region. The southern part of the Region is bordered by three countries: Equatorial Guinea, Gabon and the Republic of Congo. This Region, which is made up of 4 departments covers an area of $47,110 \mathrm{~km}^{2}$ and is home to more than 534.900 inhabitants in 2012. Its density (and hence its population) has doubled between the 1976 and 2005 censuses, from 6.7 to 13.4 inhabitants per $\mathrm{km}^{2}$. It represents $3.6 \%$ of the total population of Cameroon in 2005. The natural vegetation of the South Region is a littoral Atlantic forest. This forest extends practically only in plain and does not go back beyond $100 \mathrm{~m}$ of altitude. The fauna is particularly abundant, including the blue duiker of the forests (Cephalophus monticola), the yellow-backed duiker (Cephalophus sylvicultor), the porcupine (Atherurus africanus), the giant pangolin (Manisgigantea) and the chimpanzee (Pantroglodytes).

\section{Ethnobotanical Survey}

An ethnobotanical survey was carried out in March 2016 through semi-structured interviews Betti et al. in some major towns and their corresponding villages of the two Regions which included: Bertoua, Abong Mbang and Batouri in the East Region; Sangmelima, Ebolowa and Oveng in the South Region (Figure-1) [21]. The choice of the village was based on its proximity to the major town, presence of an existing forest and the availability of tradi-practitioners to consent to an interview. After a first prospection in the main markets of the major towns of the two Regions; several actors of the traditional pharmacopoeia were contacted. In addition to contributing to the survey itself, they also provided information that guided the surveys in the corresponding villages. The age group and gender of the different respondents; and the different plants cited used in the traditional pharmacopoeia against hemorroidal disease were indicated. These surveys included harvesters and sellers of Non-Timber Forest Products (NTFPs) more precisely medicinal plants in the major towns and inhabitants of the corresponding villages, traditional knowledge holders, healers, midwives and actors of traditional medicine in the villages. The respondents' approach was based on dialogue in French and local languages and a sample of at least 30 respondents per Region were obtained. The mode of preparation of the recipe was cited by the respondents with focus on hemorrhoidal disease treated in the traditional way, herbal plants used to cure them, their mode of administration, pharmaceutical presentation of drugs and other ailments treated by anti hemorrhoidal plant species. Furthermore, the sex and age of their patient, reason and symptom of hemorroidal disease and eventual pathology which could be linked to hemorroidal disease was indicated.

\section{Harvest and identification of medicinal plant species}

For any plant species cited, the vernacular names of the plants were recorded and the botanical descriptions of the plant species were recorded. Sample collections were done in situ by the interviewees, often accompanied by the interview guide, who made themselves available to enter the bush to collect the plant organs required for the treatment of the hemorroidal disease. Thus, the different methods of sample collection and the different plant organs harvested were recorded. Snapshots of the harvested samples were taken and then stored in a control herbarium according to the techniques and methods of Schnell [22]. These plant species were then identified at the National Herbarium of Cameroon (NHC) by a specialist (Botanist).

\section{Relative Importance of Medicinal Plants species}

Gathering semi-quantitative ethnobotanical data is a useful tool to identify the most promising pharmacological plants. It has been stated that such semi-quantitative information increases the likelihood of finding promising ethnopharmacological leads [23]. The relative importance of the plants cited by the respondent's against hemorroidal disease was established here based on the number of citations that occurred in the recipes. A given plant species was considered as important when it is cited at least twice for treating any ailment. The more the number of citation of a plant for a given ailment, the more the plant is confirmed for its use in traditional medicine for treating that ailment [21].

\section{Preliminary phytochemical screening test of some medicinal plant species}

Phytochemical screening of the drug obtained by aqueous extraction of the powder of plant specimen was performed qualitatively according to the standard methods of coloring and precipitation [24, 25]. This analysis determines the composition of secondary 
metabolites such as flavonoids (Cyanidine test), alkaloids (Dragendorff's test), saponins (Frothing test), triterpenes and steroids (Liebermann-Buchard test), polyphenolic compounds and tannins (Ferric chloride test) and coumarins (Visualization of the chromatogram at the $365 \mathrm{~nm}$ ) in the plant species [26, 27].

\section{RESULTS}

\section{Knowledge of hemorrhoidal disease by healers}

The tradi-practitioners were averagely 38 years of age with an average experience of 17 years. Most of the tradi-practitioners were females $(56 \%)$ as opposed to men $(44 \%)$. Two types of hemorrhoids were distinguished: the internal hemorrhoids and the external hemorrhoids. The tradi-practitioners indicated more male $(65 \%)$ patients than female $(35 \%)$ patients. Patients who approached the tradi-practitioners to seek treatment for hemorrhoids were mostly men $(66 \%)$ between the age group of 35-60 years. Of the 78 tradi- practitioners who gave an anti-hemorrhoidal recipes, $22 \%$ mention the descent of organ (prolapse of the anal canal) as the most obvious symptom in case of external hemorrhoids. In the case of internal hemorrhoids, rectal bleeding and glair (30\%), meteorism (17\%) and anal pruritus $(9 \%)$ were the symptoms mentioned by the healers. The frequency of healers who evoked at least 3 to 4 of these symptoms was reduced (5\%). Risk factors that can trigger hemorrhoidal disease include; hard foods (28\%), spicy foods (19\%) and sedentary lifestyle (especially prolonged sitting) (18\%), were the first causes of hemorrhoids. Pregnancy especially postpartum (19\%) was the most responsible factor in women for the disease hemorrhoid. Weakened erection $(30.77 \%)$, anemia $(21.79 \%)$, anal fissure, anal fistula and thrombosed external hemorrhoids (21.79\%) were the direct consequences related to hemorrhoidal disorders (Table-1).

Table-1: Knowledge of symptoms, causal factors and the consequences of hemorrhoidal disease

\begin{tabular}{|c|c|c|c|c|c|c|c|c|}
\hline \multicolumn{3}{|l|}{ Symptoms } & \multicolumn{3}{|l|}{ Causal factors } & \multicolumn{3}{|l|}{ Consequences } \\
\hline & $\mathrm{N}$ & $\%$ & & $\mathrm{~N}$ & $\%$ & & $\mathrm{~N}$ & $\%$ \\
\hline Rectal bleeding and glair & 23 & 29,48 & Too hard dishes & 22 & 28,20 & Weakened erection & 24 & 30,77 \\
\hline Prolapse of the anal canal & 17 & 21,79 & Too spicy dishes & 15 & 19,23 & Anaemia & 17 & 21,79 \\
\hline Meteorisms & 13 & 16,66 & Pregnancy & 15 & 19,23 & Anal fissures & 14 & 17,94 \\
\hline Anal seepage & 09 & 11,55 & Sedentary lifestyle & 14 & 17,94 & Prolapse & 13 & 16,66 \\
\hline Anal pruritus & 07 & 08,97 & Constipation & 09 & 11,53 & Cancer & 05 & 06,41 \\
\hline Painful perianal swelling & 05 & 06,41 & Alcohol & 02 & 02,56 & $\begin{array}{l}\text { Thrombosed external } \\
\text { hemorrhoids }\end{array}$ & 03 & 03,84 \\
\hline Other symptoms & 04 & 05,12 & Unknown causes & 01 & 01,28 & Unknown consequences & 02 & 02,56 \\
\hline
\end{tabular}

\section{Medicinal Plants and Recipes used for the treatment of hemorrhoidal disease}

Ethnobotanical surveys identified 48 plants used by tradi-practitioners from the East and South Regions of Cameroon to treat hemorrhoids and related problems (Table-2). These plants, included 35 woody and 13 herbaceous plants; distributed among 33 families, the most important of which were Euphorbiaceae and Fabaceae (4 species each), Anacardiaceae and Moraceae (3 species each). These plants were involved in the preparation of 125 recipes, most of which (83\%) are an association of two, three or even four plants. Single-species recipes (21 citations) represent $17 \%$ of total recipes, and were not often used for the treatment of hemorrhoidal diseases.

Recipes used by the tradi-practitioners of the East and South Regions were characterized in this study by the relative importance of plant parts, associated plants use in the recipes, modes of preparation and modes of administration used of these recipes. A total of twelve plant parts were cited in the pharmacopoeia used by tradi-practitioners in the East and South Region which included: leaves, leafy twigs, fruits, fruit beans, flower buds, tubers, roots, seeds, stems, stem barks, leafed stems, nuts and stones. Barks $(53.6 \%$ of citations) were the most cited plant parts followed by leaves $(27.2 \%)$ (Table-2).

Tradi-practitioners cited a total of ten modes of preparations of recipes including: grinding, grater and lay, crush and macerate in the water, pound and crush, decoction in the water, pound, crush and make a decoction in the water, grater and make a paste, decoction in the water and palm wine, crush and mix in palm oil, and lastly oil extraction. Decoction in the water for $30-45$ minutes $(64.0 \%)$ and grind, crush or triturate and add palm oil (17.6\%) were the two most important modes of preparation of recipes. A total of five different ways of administration of recipes were cited. These recipes were mostly administered through sitting bath and oral drink; twice per day (57.6\%) and the anal suppository; thrice per day (32.0\%).

\section{Relative importance of medicinal plants used for the treatment of hemorroidal diseases}

Plants of interest used for the treatment of hemorrhoidal disease were determined by the number of times they occurred in the recipes. A given plant species was considered effective for the treatment of hemorrhoidal disease when it was mentioned at least four (4) time for the treatment of this ailment. Amongst 
medicinal plants identified, Piper umbellatum Linn. was the most used species (10 citations). This herb was often used in recipes to treat external hemorrhoids. When it is internal, decoctions made from barks were much more used. These decoctions were also prescribed as sitting bath in case of prolapse due to hemorroidal disease. Ligneous species mostly used in the preparation of these decoctions were: Baillonella toxisperma Pierre, Mangifera indica Linn., Alchornea cordifolia (Schumach. \& Thonn) Müll, Spathodea campanulata P. Beauv., Morinda lucida Benth., Irvingia gabonensis (Aurey-Lecomte ex O'Rorke) Baill., Myrianthus arboreus P. Beauv., Trilepisium madagascariense DC. and Antrocaryon klaineanum L. with $4,4,5,6,6,7,7,7$ and 8 citations respectively. Two species were also plants of interest in the traditional treatment of hemorrhoids although they were only used in association with other plants in recipes. Elaeis guineensis Jacq. whose seed oil (palm kernel oil) was used in 7 recipes as solvent for the herbs used and Musa parasidiaca Linn. whose fruits or inflorescences were cut and put in decoction with the bark in 6 recipes (Table-2).

Various methods were used by healers to extract drugs from plant species. Specimens easily accessible such as leaves were usually harvested by hand and / or ripped off with the entire plant for herbaceous plants and by simple pick-up for large trees. For taller specimens, tradi-practitioners relied on special pickers (choppers). Flowers and inflorescences were pulled by hand or harvested with special pickers. Fruits of Theobroma cacao and Aframomum sp. were harvested at full maturity, by hand or by machete for fruits of Musa parasidiaca and Elaeis guineensis. Scraping was carried out with knives for the barks of the stem. Bark and root debarking of wood specimens was done by machetes.

\section{Other ailments treated by medicinal plants used for the treatment of hemorrhoidal disease}

Medicinal plants used to treat hemorrhoidal diseases are often used to treat many other diseases as indicated by tradi-practitioners of the East and South Regions of Cameroon. These other diseases have been grouped with the most recurrent group being; Inflammatory diseases especially: rheumatism (treated on average by 12 plant species), painful periods (by 10 plant species), paronychia (by 10 plant species), hernia (by 9 plant species), Pain diseases especially: toothache (treated on average by 9 plant species), backache (by 9 plant species), stomach ache (by 7 plant species), head ache (by 6 plant species), Infections diseases especially: malaria and diarrhea (treated on average by 10 plant species each), sexual infectious diseases (by 8 plant species), typhoid (by 7 plant species), diseases of the digestive system especially constipation (treated on average by 9 plant species) and diseases of the circulatory system especially: anemia (treated on average by 7 plant species), varicose veins and cardiovascular illnesses (treated on average by 6 plant species each).

Table-2: Information of medicinal plants against hemorrhoidal disease among people of East and South Region of

\begin{tabular}{|c|c|c|c|c|c|c|}
\hline $\begin{array}{l}\text { Vernacular } \\
\text { names }\end{array}$ & Scientific names & $\begin{array}{l}\text { Number } \\
\text { of } \\
\text { citations }\end{array}$ & $\begin{array}{l}\text { Plant part } \\
\text { and Biological } \\
\text { type }\end{array}$ & $\begin{array}{l}\text { Associated } \\
\text { plant }\end{array}$ & $\begin{array}{l}\text { Modes of } \\
\text { preparation }\end{array}$ & $\begin{array}{l}\text { Mode of } \\
\text { administration }\end{array}$ \\
\hline 1. Esonn & $\begin{array}{l}\text { Aframomum angustifolium } \\
\text { K. Schum. (Zingiberaceae) }\end{array}$ & 2 & Le, Fr $(\mathrm{He})$ & & Grind & $\begin{array}{l}\text { Anal } \\
\text { suppository }\end{array}$ \\
\hline 2. Ndong & $\begin{array}{l}\text { Aframomum melegueta } \mathrm{K} . \\
\text { Schum. } \\
\text { (Zingiberaceae) }\end{array}$ & 1 & $\mathrm{Fe}, \mathrm{Fr}(\mathrm{He})$ & 42 & Grind & $\begin{array}{l}\text { Anal } \\
\text { suppository }\end{array}$ \\
\hline $\begin{array}{l}\text { 3. Mbeul/ } \\
\text { Mbanga afum }\end{array}$ & $\begin{array}{l}\text { Afzelia pachyloba L. } \\
\text { (Cesalpiniaceae) }\end{array}$ & 1 & $\mathrm{Ba}(\mathrm{Tr})$ & $48+9$ & $\begin{array}{l}\text { Decoction for } \\
45 \text { minutes }\end{array}$ & $\begin{array}{l}\text { Sitting bath and } \\
\text { oral drink }\end{array}$ \\
\hline 4. Awoule & $\begin{array}{l}\text { Ageratum conyzoides } \mathrm{L} . \\
\text { (Asteraceae) }\end{array}$ & 3 & Le $(\mathrm{He})$ & $6+18+38$ & $\begin{array}{l}\text { Grind/triturate } \\
\text { and add } 18 \text { or } \\
\text { honey }\end{array}$ & $\begin{array}{l}\text { Anal } \\
\text { suppository }\end{array}$ \\
\hline 5. Yando/ Aboe & $\begin{array}{lr}\text { Alchornea } & \text { cordifolia } \\
\text { (Schumach. \& } & \text { Thonn) } \\
\text { Müll. } & \text { Arg. } \\
\text { (Euphorbiaceae) } & \\
\text { IC: 40512/NHC } & \\
\end{array}$ & 5 & Le (Tr-li) & $7+24+29$ & $\begin{array}{l}\text { Decoction for } \\
45 \text { minutes }\end{array}$ & $\begin{array}{l}\text { Sitting bath and } \\
\text { oral drink }\end{array}$ \\
\hline $\begin{array}{l}6 . \quad \text { Macabo } \\
\text { sauvage }\end{array}$ & $\begin{array}{l}\text { Anchomanas difformis } \\
\text { (Blume) Engl. (Araceae) }\end{array}$ & 2 & $\mathrm{Tu}(\mathrm{He})$ & 38 & $\begin{array}{l}\text { Grater and lay } \\
\text { on the leaves of } \\
38\end{array}$ & Garniture anale \\
\hline 7. Ebomm & $\begin{array}{l}\text { Annona senegalensis Pers. } \\
\text { (Annonaceae) }\end{array}$ & 2 & $\mathrm{Ba}(\mathrm{Tr})$ & $11+48$ & $\begin{array}{l}\text { Decoction for } \\
45 \text { minutes }\end{array}$ & Sitting bath \\
\hline 8. Ayinda & $\begin{array}{l}\text { Anthocleista schweinfurthii } \\
\text { Gilg. (Loganiaceae) }\end{array}$ & 1 & $\mathrm{Ba}(\mathrm{Tr})$ & 44 & $\begin{array}{l}\text { Decoction for } \\
45 \text { minutes }\end{array}$ & $\begin{array}{l}\text { Sitting bath and } \\
\text { oral drink }\end{array}$ \\
\hline 9. Ngonhoo & $\begin{array}{l}\text { Antrocaryon klaineanum } \\
\text { L. (Anacardiaceae) IC: } \\
\text { 1742/SRFC }\end{array}$ & 8 & $\mathrm{Ba}(\mathrm{Tr})$ & $21+28$ & $\begin{array}{l}\text { Decoction for } \\
45 \text { minutes }\end{array}$ & $\begin{array}{l}\text { Sitting bath and } \\
\text { oral drink }\end{array}$ \\
\hline
\end{tabular}


Patrice Brice Mvogo Ottou et al; Saudi J Med Pharm Sci, April., 2020; 6(4): 321-333

\begin{tabular}{|c|c|c|c|c|c|c|}
\hline 10. Ndouom go & $\begin{array}{l}\text { Asparagus racemosus } \\
\text { Willd. (Aparagaceae) }\end{array}$ & 2 & $\mathrm{Ro}(\mathrm{He})$ & 45 & $\begin{array}{l}\text { Crush and } \\
\text { macerate in } \\
\text { water with } 45\end{array}$ & Rectal (purge) \\
\hline $\begin{array}{l}11 . \\
\text { Adjap/Ayapp }\end{array}$ & $\begin{array}{l}\text { Baillonella toxisperma } \\
\text { Pierre (Sapotaceae) } \\
\text { IC: 7372/SRFC }\end{array}$ & 4 & $\mathrm{Ba}(\operatorname{Tr})$ & $22+13$ & $\begin{array}{l}\text { Decoction for } \\
45 \text { minutes }\end{array}$ & Sitting bath \\
\hline 12. Koalngoasse & $\begin{array}{l}\text { Bidens pilosa } \\
\text { (Asteraceae) }\end{array}$ & 1 & Le (He) & 38 & $\begin{array}{l}\text { Grind/triturate } \\
\text { and add } 18\end{array}$ & $\begin{array}{l}\text { Anal } \\
\text { suppository }\end{array}$ \\
\hline 13. Aiele/Abel & $\begin{array}{l}\text { Canarium schweinfurthii } \\
\text { Engl. (Burseraceae) }\end{array}$ & 2 & $\mathrm{Ba}(\mathrm{Tr})$ & $31+48$ & $\begin{array}{l}\text { Grind/triturate } \\
\text { and add } 18\end{array}$ & Sitting bath \\
\hline 14. & $\begin{array}{l}\text { Chenopodium } \\
\text { ambrosioides (L.) Mos. \& } \\
\text { Clem. (Chenopodiaceae) }\end{array}$ & 2 & Le-st (He) & $38+18$ & $\begin{array}{l}\text { Grind/triturate } \\
\text { and add } 18\end{array}$ & $\begin{array}{l}\text { Anal } \\
\text { suppository }\end{array}$ \\
\hline $\begin{array}{ll}15 . & \text { Abine } \\
\text { ntomba } & \end{array}$ & $\begin{array}{l}\text { Cnestis ferruginea Vahl ex } \\
\text { DC. (Connaraceae) }\end{array}$ & 1 & Le, St-ba (Tr) & 31 & $\begin{array}{l}\text { Decoction for } \\
45 \text { minutes }\end{array}$ & $\begin{array}{l}\text { Sitting bath and } \\
\text { oral drink }\end{array}$ \\
\hline $\begin{array}{lr}16 . & \text { Ewomen } \\
\text { (arbre } & \text { du } \\
\text { noisetier } & \\
\end{array}$ & $\begin{array}{l}\text { Coula edulis Baill. } \\
\text { (Olocaceae) }\end{array}$ & 1 & $\mathrm{Ba}(\mathrm{Tr})$ & & $\begin{array}{l}\text { Decoction for } \\
30-45 \text { minutes }\end{array}$ & $\begin{array}{l}\text { Sitting bath and } \\
\text { oral drink }\end{array}$ \\
\hline $\begin{array}{ll}17 . & \text { Dubo/ } \\
\text { Mevini } & \\
\end{array}$ & $\begin{array}{l}\text { Diospyros crassiflora } \\
\text { Hiern (Ebenaceae) }\end{array}$ & 1 & $\mathrm{Ba}(\mathrm{Tr})$ & $9+21+28+29$ & $\begin{array}{l}\text { Decoction for } \\
45 \text { minutes }\end{array}$ & Sitting bath \\
\hline $\begin{array}{l}\text { 18. Manyanga / } \\
\text { Mbila Alen }\end{array}$ & 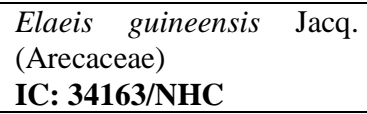 & 7 & $\mathrm{Nu}(\mathrm{Su}-\mathrm{sh})$ & $38+4$ & $\begin{array}{l}\text { Grind/triturate } \\
\text { and add } 18\end{array}$ & $\begin{array}{l}\text { Anal } \\
\text { suppository }\end{array}$ \\
\hline 19. Akol & $\begin{array}{l}\text { Ficus exasperata Vahl. } \\
\text { (Moraceae) }\end{array}$ & 1 & $\mathrm{Ba}, \mathrm{Le}(\mathrm{Tr})$ & $44+29$ & $\begin{array}{l}\text { Decoction for } \\
45 \text { minutes }\end{array}$ & Sitting bath \\
\hline $\begin{array}{l}20 . \\
\text { Kpwasèlè/Sélé }\end{array}$ & $\begin{array}{l}\text { Haumania } \\
\text { danckelmaniana (Braun \& } \\
\text { K. Schum.) Milne-Redh. } \\
\text { (Marantaceae) }\end{array}$ & 2 & $\mathrm{Le}(\mathrm{He})$ & & Crush/triturate & $\begin{array}{l}\text { Anal } \\
\text { suppository }\end{array}$ \\
\hline $\begin{array}{ll}21 . & \text { Andokk } \\
\text { Osoe } & \end{array}$ & $\begin{array}{lr}\text { Irvingia } & \text { gabonensis } \\
\text { (Aurey-Lecomte } & \text { ex } \\
\text { O'Rorke) } & \text { Baill. } \\
\text { (Irvingiaceae) } & \\
\text { IC: } 28054 / \text { NHC } & \\
\end{array}$ & 7 & $\mathrm{Ba}(\mathrm{Tr})$ & $9+21+29$ & $\begin{array}{l}\text { Decoction for } \\
45 \text { minutes }\end{array}$ & $\begin{array}{l}\text { Sitting bath and } \\
\text { oral drink }\end{array}$ \\
\hline 22. Eveuss & $\begin{array}{l}\text { Klainedoxa gabonensis } \\
\text { Pierre (Irvingiaceae) }\end{array}$ & 2 & $\mathrm{Ba}(\mathrm{Tr})$ & $31+48$ & $\begin{array}{l}\text { Decoction for } \\
30-45 \text { minutes }\end{array}$ & Sitting bath \\
\hline $\begin{array}{lr}23 . & \text { Ahom } \\
\text { ndamba/Boureu } \\
\text { h }\end{array}$ & $\begin{array}{l}\text { Landolphia owariensis } \mathrm{P} . \\
\text { Beauv. (Apocynaceae) }\end{array}$ & 1 & Le, St-ba (Li) & $5+28$ & $\begin{array}{l}\text { Decoction for } \\
45 \text { minutes }\end{array}$ & $\begin{array}{l}\text { Sitting bath and } \\
\text { oral drink }\end{array}$ \\
\hline 24. Manguier/ & $\begin{array}{l}\text { Mangifera indica L. } \\
\text { (Annarcadiaceae) } \\
\text { IC } \mathbf{:} \mathbf{2 0 0 3 4} / \mathbf{N H C}\end{array}$ & 4 & Ec $(\operatorname{Tr})$ & $5+21$ & $\begin{array}{l}\text { Decoction for } \\
45 \text { minutes }\end{array}$ & Sitting bath \\
\hline $\begin{array}{l}25 . \quad \text { Koussa/ } \\
\text { Ekokolet }\end{array}$ & $\begin{array}{lr}\begin{array}{l}\text { Manniophyton } \\
\text { Mull. } \\
\text { (Euphorbiaceae) }\end{array} & \text { Aulvum } \\
\end{array}$ & 1 & See, Fe (Sh) & $20+38$ & $\begin{array}{l}\text { Pound and crush } \\
\text { leaves }\end{array}$ & $\begin{array}{l}\text { Application } \\
\text { anale }\end{array}$ \\
\hline 26. Okekela & $\begin{array}{l}\text { Mareya micrantha } \\
\text { (Benth.) Müll. Arg. } \\
\text { (Euphorbiaceae) }\end{array}$ & 1 & Le-tw (Sh) & & $\begin{array}{l}\text { Decoction for } \\
45 \text { minutes }\end{array}$ & Bain de siège \\
\hline 27. Wogossono & $\begin{array}{ll}\text { Mimosa pudica } & \text { L. } \\
\text { (Mimosaceae) }\end{array}$ & 1 & $\mathrm{Le}(\mathrm{He})$ & $18+38+43$ & $\begin{array}{l}\text { Crush and mix } \\
\text { in } 18\end{array}$ & $\begin{array}{l}\text { Anal } \\
\text { suppository }\end{array}$ \\
\hline 28. Keunn & $\begin{array}{l}\text { Morinda lucida Benth. } \\
\text { (Rubiaceae) } \\
\text { IC: } \mathbf{4 6 4 4 7 / N H C}\end{array}$ & 6 & $\mathrm{Ba}(\mathrm{Tr})$ & $5+11+21$ & $\begin{array}{l}\text { Decoction for } \\
30-45 \text { minutes }\end{array}$ & $\begin{array}{l}\text { Sitting bath and } \\
\text { oral drink }\end{array}$ \\
\hline 29. Bananier & $\begin{array}{l}\text { Musa parasidiaca L. } \\
\text { (Musaceae) } \\
\text { No specimen at the NHC }\end{array}$ & 6 & $\begin{array}{l}\text { Fr, Fl-bu (Su- } \\
\text { sh) }\end{array}$ & $9+28+31+44$ & $\begin{array}{l}\text { Decoction for } \\
45 \text { minutes by } \\
\text { adding } 2 \text { fruitlet } \\
\text { of plantains not } \\
\text { walls cut into } \\
\text { small pieces }\end{array}$ & $\begin{array}{l}\text { Sitting bath, } \\
\text { oral drink and } \\
\text { eat } 29\end{array}$ \\
\hline $\begin{array}{l}30 . \\
\text { Asseng/Kombo }\end{array}$ & $\begin{array}{l}\text { Musanga cecropioides } \mathrm{R} . \\
\mathrm{Br} \text {. (Cecropiaceae) }\end{array}$ & 2 & Le, St-ba (Tr) & & & Oral drink \\
\hline $\begin{array}{l}31 . \\
\text { Engokommo/ } \\
\text { Ngata }\end{array}$ & $\begin{array}{l}\text { Myrianthus arboreus P. } \\
\text { Beauv. (Moraceae) IC: } \\
\text { 12832/Forestry Research } \\
\text { section of Cameroon }\end{array}$ & 7 & Le, $\mathrm{Ba}(\mathrm{Tr})$ & 48 & $\begin{array}{l}\text { Decoction for } \\
45 \text { minutes }\end{array}$ & $\begin{array}{l}\text { Sitting bath and } \\
\text { oral drink }\end{array}$ \\
\hline
\end{tabular}


Patrice Brice Mvogo Ottou et al; Saudi J Med Pharm Sci, April., 2020; 6(4): 321-333

\begin{tabular}{|c|c|c|c|c|c|c|}
\hline 32. Mbikam & $\begin{array}{lrr}\text { Newbouldia } & \text { laevis }(\mathrm{P} . \\
\text { Beauv.) } & \text { Seem. } \\
\text { (Bignoniaceae) } & \end{array}$ & 1 & Ba et Ro (Tr) & $5+9+14+24$ & $\begin{array}{l}\text { Decoction for } \\
45 \text { minutes }\end{array}$ & $\begin{array}{l}\text { Sitting bath and } \\
\text { oral drink }\end{array}$ \\
\hline 33. Akega & $\begin{array}{l}\text { Palisota barteri Hook } \\
\text { (Commelinaceae) }\end{array}$ & 1 & $\mathrm{Le}(\mathrm{He})$ & & $\begin{array}{l}\text { Burn and crush } \\
\text { the shell of the } \\
\text { turtle, then } \\
\text { crush } 38 \text { and red } \\
\text { mushroom } \\
\text { growing from } \\
\text { the ground }\end{array}$ & Rectal (purge) \\
\hline $\begin{array}{l}34 . \\
\text { Choueing/Esson } \\
\mathrm{g}\end{array}$ & $\begin{array}{l}\text { Panicum maximum Jacq. } \\
\text { (Poaceae) }\end{array}$ & 1 & Le-st $(\mathrm{He})$ & & $\begin{array}{l}\text { Decoction by } \\
\text { adding carapace } \\
\text { of the turtle and } \\
\text { red mushroom } \\
\text { growing from } \\
\text { the ground }\end{array}$ & Rectal (purge) \\
\hline 35. Nlom & $\begin{array}{l}\text { Paullinia pinnata L. } \\
\text { (Sapindaceae) }\end{array}$ & 1 & Le-st (Sh) & & $\begin{array}{l}\text { Pound, crush } \\
\text { and make a } \\
\text { decoction for } 45 \\
\text { minutes with the } \\
\text { red mushroom } \\
\text { and turtle bones }\end{array}$ & $\begin{array}{l}\text { Anal } \\
\text { suppository } \\
\text { oral drink }\end{array}$ \\
\hline 36. Bendeuu & $\begin{array}{l}\text { Pentadiplandra brazzeana } \\
\text { (Pentadiplandraceae) }\end{array}$ & 1 & $\mathrm{Ba}(\operatorname{Tr})$ & $9+11+45$ & $\begin{array}{l}\text { Decoction for } \\
45 \text { minutes }\end{array}$ & $\begin{array}{l}\text { Oral drink and } \\
\text { sitting bath }\end{array}$ \\
\hline 37. Pia & $\begin{array}{l}\text { Persea americana Mill. } \\
\text { (Lauraceae) }\end{array}$ & 1 & Sto $(\mathrm{Tr})$ & & $\begin{array}{l}\text { Grater and make } \\
\text { a paste, } \\
\text { Decoction of the } \\
\text { stones }\end{array}$ & $\begin{array}{l}\text { Anal } \\
\text { suppository }\end{array}$ \\
\hline 38. Mebomla & $\begin{array}{l}\text { Piper umbellatum L. } \\
\text { (Piperaceae) } \\
\text { IC } \mathbf{: 6 1 2 2 0 /} \mathbf{N H C}\end{array}$ & 10 & Le (He) & & $\begin{array}{l}\text { To crush or et } \\
\text { use the whole } \\
\text { leaves }\end{array}$ & $\begin{array}{l}\text { Anal } \\
\text { suppository } \\
\text { rectal (garnish) }\end{array}$ \\
\hline 39. Mbel & $\begin{array}{l}\text { Pterocarpus soyauxii } \\
\text { Hooker (Fabaceae) }\end{array}$ & 1 & $\mathrm{Ba}(\mathrm{Tr})$ & 44 & Decoction & Sitting bath \\
\hline $\begin{array}{ll}40 . & \text { Jong/ } \\
\text { Elebeng } & \end{array}$ & $\begin{array}{l}\text { Ricinus communis L. } \\
\text { (Euphorbiaceae) }\end{array}$ & 1 & $\begin{array}{l}\text { Le, St-ba (Su- } \\
\text { sh) }\end{array}$ & 38 & $\begin{array}{l}\text { Grater, macerate } \\
\text { and triturate the } \\
\text { leaves of } 38\end{array}$ & Purge \\
\hline $\begin{array}{l}41 . \\
\text { Bidou/Ozouga }\end{array}$ & $\begin{array}{l}\text { Saccoglottis gabonensis L. } \\
\text { (Humiriaceae) }\end{array}$ & 1 & $\mathrm{Ba}(\mathrm{Tr})$ & 30 & Decoction & Sitting bath \\
\hline 42. Olom & $\begin{array}{l}\text { Scorodophloeus zenkeri } \\
\text { Harms (Caesalpiniaceae) }\end{array}$ & 2 & $\mathrm{Ba}(\mathrm{Tr})$ & 1 & $\begin{array}{l}\text { Pound, crush } \\
\text { and make a } \\
\text { paste }\end{array}$ & $\begin{array}{l}\text { Anal } \\
\text { suppository }\end{array}$ \\
\hline 43. Shimbouleu & $\begin{array}{l}\text { Sida acuta Burm. FI. Ind. } \\
\text { (Malvaceae) }\end{array}$ & 2 & $\mathrm{Le}(\mathrm{He})$ & $4+18$ & $\begin{array}{l}\text { Grind/triturate } \\
\text { and add } 18\end{array}$ & $\begin{array}{l}\text { Anal } \\
\text { suppository }\end{array}$ \\
\hline $\begin{array}{l}\text { 44. Evevon/ } \\
\text { Kibobola }\end{array}$ & $\begin{array}{l}\text { Spathodea campanulata } \mathrm{P} \text {. } \\
\text { Beauv. (Bignoniaceae) IC: } \\
\text { 45706/NHC }\end{array}$ & 6 & $\mathrm{Ba}(\mathrm{Tr})$ & $31+48$ & $\begin{array}{l}\text { Decoction for } \\
30-45 \text { minutes }\end{array}$ & $\begin{array}{l}\text { Sitting bath and } \\
\text { oral drink }\end{array}$ \\
\hline $\begin{array}{l}45 . \\
\text { Etoan/Pandoo } \\
\end{array}$ & $\begin{array}{l}\text { Tabernaemontana crassa } \\
\text { Benth. (Apocynaceae) }\end{array}$ & 3 & $\mathrm{Ba}(\mathrm{Tr})$ & $10+38$ & Decoction & $\begin{array}{l}\text { Oral drink and } \\
\text { purge }\end{array}$ \\
\hline $\begin{array}{l}46 . \\
\text { Keukeu/Cacao }\end{array}$ & $\begin{array}{l}\text { Theobroma cacao L. } \\
\text { (Sterculiaceae) }\end{array}$ & 1 & Fr-be (Tr) & & $\begin{array}{l}\text { Collect oil or } \\
\text { cocoa butter }\end{array}$ & $\begin{array}{l}\text { Anal unction } \\
\text { and oral drink }\end{array}$ \\
\hline $\begin{array}{l}47 . \\
\text { Ekong/Ngoyoo }\end{array}$ & $\begin{array}{l}\text { Trichoscypha acuminata } \\
\text { Engl. (Anacardiaceae) }\end{array}$ & 1 & $\mathrm{Ba}(\mathrm{Tr})$ & $9+21+28$ & $\begin{array}{l}\text { Decoction for } \\
45 \text { minutes }\end{array}$ & $\begin{array}{l}\text { Sitting bath and } \\
\text { oral drink }\end{array}$ \\
\hline 48. Zolibieuh & $\begin{array}{l}\text { Trilepisium } \\
\text { madagascariense } \\
\text { (Moraceae) } \\
\text { 64304/NHC } \\
\end{array}$ & 7 & $\mathrm{Ba}(\mathrm{Tr})$ & $29+31+44$ & $\begin{array}{l}\text { Decoction with } \\
\text { water+palm } \\
\text { wine }\end{array}$ & Sitting bath \\
\hline
\end{tabular}

Le=Leaves, Ba= Barks, Tu=Tubers, Ro=Roots, Le-st=Leafed stems, St-ba=Stem bark, Nu=Nuts, See=Seeds, Le-tw=Leafy twigs, Flbu=Flower buds, Sto=Stones, Fr-be=Fruit beans, He= Herbs, Sh=Shrubs, Tr= Trees, Tri-li= Tree-liana, Li=Liana, Su-sh=Subshrubs, IC = Identification Code, $\mathrm{CNH}=$ National Herbarium of Cameroon, FRSC=Forestry Research Section of Cameroon 


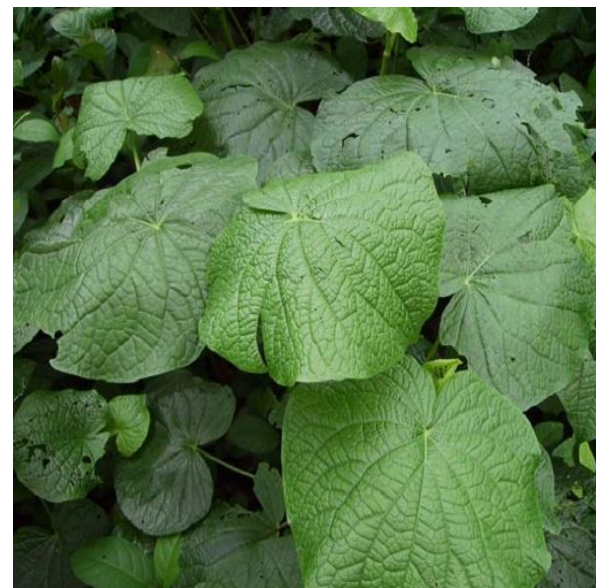

Leaves of Piper umbellatum harvested at Olounou (South Region). This species is a perennial herb found in pan-tropical. The Baka people use it for the treatment of burns, paronychia and toothaches. In some villages of the South Region these leaves are eaten as a dish.

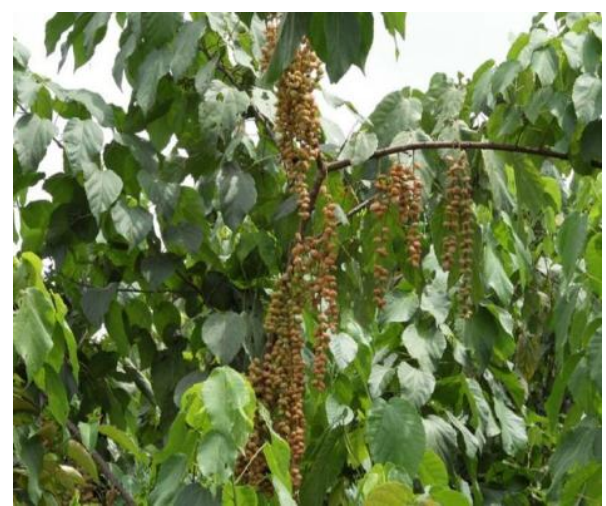

Leaves and fruits of Alchornea cordifolia harvested at Nkouole (East Region). This species is a shrub liana found in tropical Africa. Tradi-practitioners of the villages in the South Region use for it for the treatment of anemia, malaria and toothaches while in the East Region, it is used as a purgative and in treatment of dysentery.

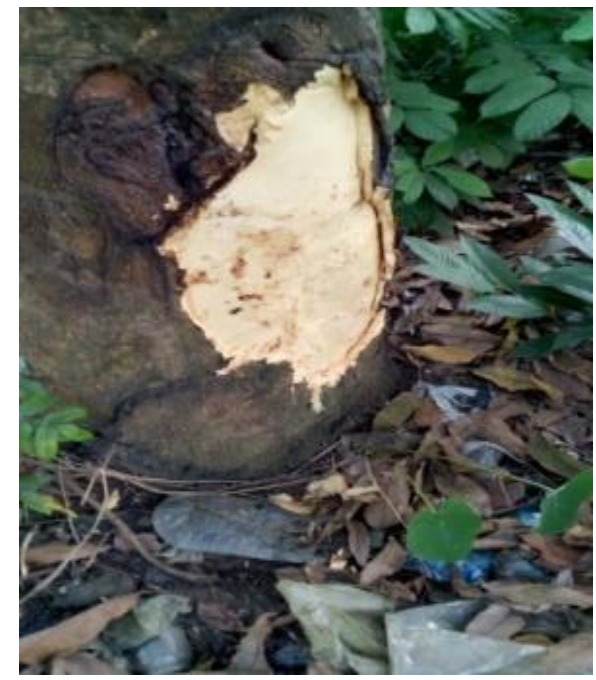

Unbarked trees of Mangifera indica harvested at Nkouole (East Region). This species is widely cultivated in pan-tropical zone. Healers of the East Region use it to treat gingivitis, rheumatism, back pain and malaria. In some villages of the south Region barks are usually used for the treatment of sexual infections and to lower blood pressure.

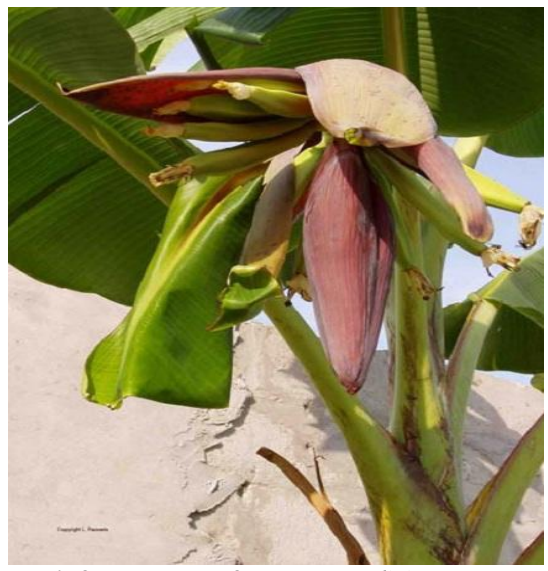

Leaves and inflorescence of Musa paradisiaca harvested from Olounou (South Region). This species is shrub widely cultivated in pan-tropical zones. Leaves are usually used by tradipractitioners as a traditional funnel to heat recipes under low heat and to give recipes for the treatment of respiratory diseases by nasal inhalation.

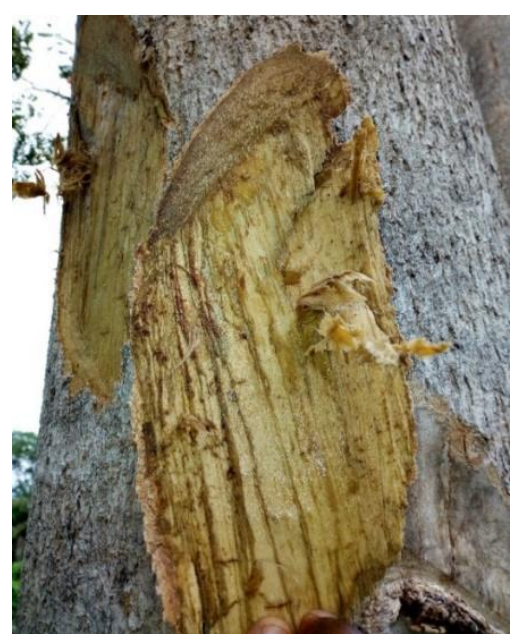

Unbarked trees of Spathodea campanulata harvested at Kwoamn (Baka village) (East Region). This plant is a Guinean-Congolese species found in secondary forests. In the East Region, healers use

it for the treatment of gastrointestinal problems such as constipation, diarrhea and gastric ulcers.

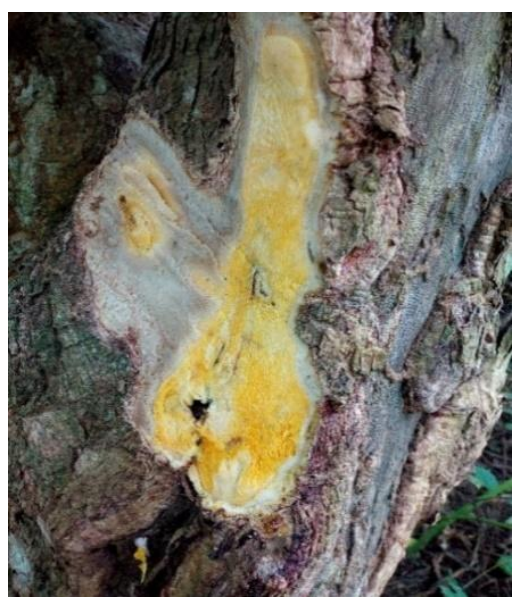

Unbarked trees of Morinda lucida campanulata harvested from Engom I (South Region). This species is a secondary forests tree found in tropical Africa zone. Healers of the East Region usually use it to treat malaria, typhoid and jaundice. In some villages of the South Region it is used for the treatment of the sexual infections and hepatitis. 


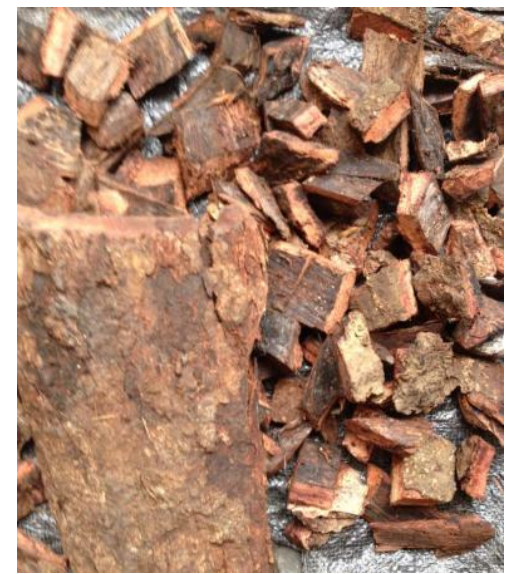

Stem Barks of Antrocaryon klaineanum harvested from Olounou (South Region). This species is found in primary or none disturbed forests in tropical Africa zone. Healers of the East Region use it to relieve painful periods and sore. In villages of the South Region it is used for the treatment of the sexual infections.

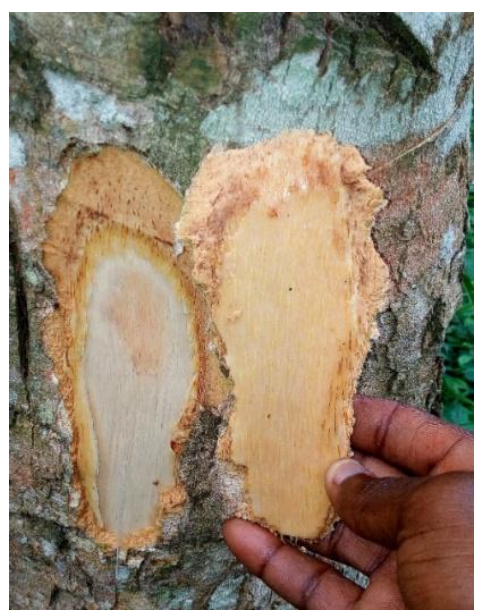

Unbarked trees of Irvingia gabonensis harvested at Engong (South Region). This plant is a Guinean-Congolese species found in primary or none disturbed forests. Healers of the East Region use it to relieve pain and to treat scratch. Seeds of the fruits are used to cook Cameroonian dishes.

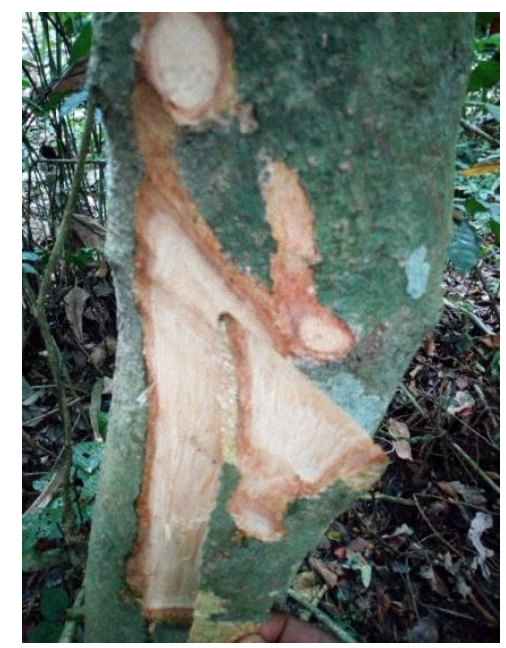

Unbarked trees of Myrianthus arboreus harvested at Kwoamn (Baka village) (East Region). This species is a secondary forest tree found in Guinean-Congolese zone. From the East Region, healers use it as an analgesic to treat muscle pain, fractures and headaches. In the South Region it is used for the treatment of amoebic dysentery.

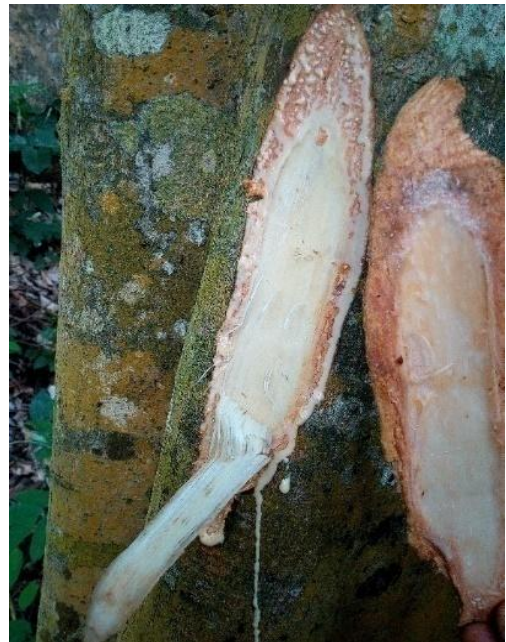

Unbarked trees of Trilepisium madagascariense harvested at Olounou (South Region). It is a secondary forests tree found in tropical Africa. From the East Region, healers use barks to lower blood pressure and rapid healing of wounds. From the South

Region, healers use it for treatment of varicose veins and cardiovascular illnesses.

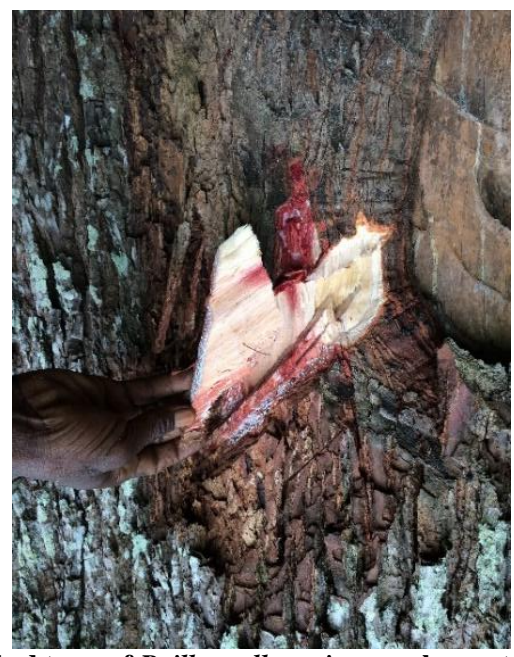

Unbarked trees of Baillonnella toxisperma harvested from Olounou (South Region). This species is a primary or none disturbed forest tree found in Guinean-Congolese zone. Healers usually use it for the treatment of kidney pain, back pain, toothaches, some sexual infections and respiratory diseases.

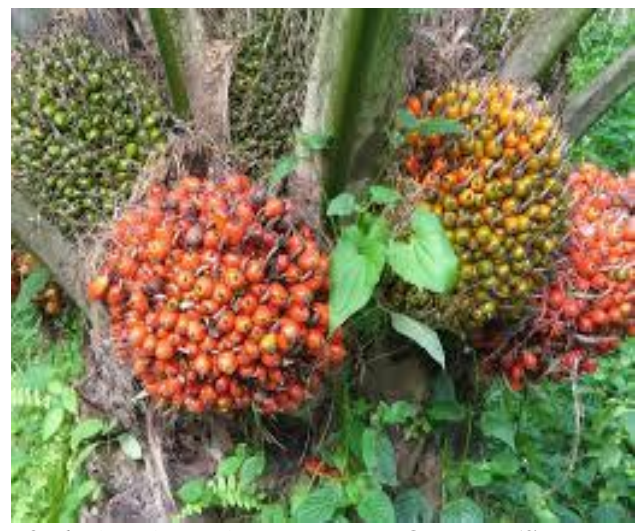

Nuts of Elaeis guineensis harvested at Olounou (South Region). Elaeis guineensis is an under shrub widely cultivated in the pantropical zone. Palm kernel oil of this plant are usually used by healers to lower fever in traditional pediatrics. This oil is usually used as a solvent by healers in traditional medicine. 
Preliminary chemical screening test of some plant species

After performing the analysis of bioactive compounds of the studied medicinal plants extracts, results indicated that, phytochemical compounds such as steroids, alkaloids, phenolics, coumarines, triterpenes, tannins, saponins, flavonoids, were detected. The results revealed that phenolic compounds were found in eight of the ten plants, with Irvingia gabonensis, Myrianthus arboreus, Trilepisium madagascariense, Spathodea campanulata, Baillonella toxisperma and Mangifera indica extracts being very rich in these compounds (Table-3).

Table-3: Preliminary phytochemical analysis of some plant species

\begin{tabular}{|c|c|c|c|c|c|c|c|c|c|c|}
\hline & oups & hen & cons & nts & & & & & & \\
\hline $\begin{array}{l}\text { Aqueous extract } \\
\text { of drugs }\end{array}$ & Phe & Tan & Ant & Alk & Tri & Antr & Fla & Ste & Cou & Sap \\
\hline $\begin{array}{l}\text { Piper } \\
\text { umbellatum }\end{array}$ & ++ & ++ & - & ++ & + & - & + & + & - & - \\
\hline Morinda lucida & + & _ & - & - & ++ & ++ & - & - & + & - \\
\hline $\begin{array}{l}\text { Antrocaryon } \\
\text { klaineanum }\end{array}$ & + & + & - & - & + & ++ & - & ++ & ++ & + \\
\hline $\begin{array}{l}\text { Irvingia } \\
\text { gabonensis }\end{array}$ & ++ & + & + & ++ & + & + & + & + & + & + \\
\hline $\begin{array}{l}\text { Myrianthus } \\
\text { arboreus }\end{array}$ & ++ & ++ & + & ++ & + & ++ & ++ & + & ++ & + \\
\hline $\begin{array}{l}\text { Trilepisium } \\
\text { madagascariense }\end{array}$ & ++ & ++ & - & + & ++ & ++ & + & + & ++ & - \\
\hline $\begin{array}{l}\text { Spathodea } \\
\text { campanulata }\end{array}$ & ++ & + & + & ++ & - & + & + & - & + & - \\
\hline $\begin{array}{l}\text { Alchornea } \\
\text { cordifolia }\end{array}$ & - & ++ & + & - & ++ & - & + & ++ & - & + \\
\hline $\begin{array}{l}\text { Baillonella } \\
\text { toxisperma }\end{array}$ & ++ & ++ & + & - & + & - & ++ & + & + & + \\
\hline Mangifera indica & ++ & ++ & + & + & + & - & ++ & ++ & + & + \\
\hline $\begin{array}{l}\text { Characteristic } \\
\text { coloring }\end{array}$ & $\begin{array}{l}\text { Bluish- } \\
\text { green } \\
\text { coloration }\end{array}$ & $\begin{array}{l}\text { Green } \\
\text { or } \\
\text { dark- } \\
\text { blue } \\
\end{array}$ & $\begin{array}{l}\text { Purplish } \\
\text { red } \\
\text { coloration }\end{array}$ & $\begin{array}{l}\text { Formation } \\
\text { of a a } \\
\text { precipitate }\end{array}$ & $\begin{array}{l}\text { Purple } \\
\text { coloration }\end{array}$ & $\begin{array}{l}\text { Purplish } \\
\text { blue } \\
\text { coloration }\end{array}$ & $\begin{array}{l}\text { Yellow } \\
\text { precipi- } \\
\text { tate }\end{array}$ & $\begin{array}{l}\text { Bluish- } \\
\text { green } \\
\text { coloration }\end{array}$ & $\begin{array}{l}\text { Yellow } \\
\text { green } \\
\text { fluores- } \\
\text { cence }\end{array}$ & $\begin{array}{l}\text { Persistent } \\
\text { foam } \\
\text { index }\end{array}$ \\
\hline
\end{tabular}

The popular colorimetric methods for identify chemicals groups on plant parts. All tests are replicated twice Phe=phenolic compounds, Tri=triterpenes, Alk=alkaloids, Tan=tannins, Antr=anthraquinones, Fla=flavonoids, Ste $=$ steroids, Cou=coumarines, Sap $=$ saponins, Ant $=$ anthocyanins ++ Present in high concentration, + present in low concentration, - not detected

\section{DiSCUSSION}

Hemorrhoids are called "Ikong" in the Maka dialect and "ko'oto" in the Bulu dialect in the East and South Regions of the country respectively. The age of the tradi-practitioners is in corroboration with those found in other studies [20, 28]. Dibong et al., indicated that the age, the origin and the period of experience in the profession is an advantage to the credibility of the informants during a survey [20]. There were more female tradi-practitioners than males. This may be due to the fact that patients may feel more comfortable with tradi-practitioners of the opposite sex; taking into consideration that there were more male patients than female patients. Most of the tradi-practitioners indicated that there were two types of hemorrhoidal diseases; consistent with the results of Higuero [14]. The causes of hemorrhoidal diseases mentioned by tradipractitioners were in corroboration with those mentioned by other authors [8, 14, 29]. However this is contrary to the results obtained by Boureima in Mali who indicated that amongst the 56 respondents, 13 incriminate prolonged sitting position and only one (01) mentions stages of the female reproductive cycle [3]. The symptoms indicated are in corroboration with those obtained by Higuero; who indicated that external hemorrhoidal illnesses appear in the form of thromboses that can lead to scours and that rectorragias and / or prolapse are generally signs of internal hemorrhoids [14]. These symptoms may be due to the eating habits and lack of regular exercise (sedentary lifestyle) of people in the Southeastern region of Cameroon.

Treatments from medicine plants were easily accessible. They are therefore the best therapeutic alternative for patients suffering from hemorrhoids of various types as they prove their effectiveness in relieving symptoms related to these ailments. Several methods have been used by different authors to select the most important plants used in traditional medicine which include the factor of informant consensus, the fidelity level, Use-Values, disease-consensus index, simple percentage, Relative Importance Index [6, 20, 
21, 30-32]. Whatever the approach used, the most important and first step to follow is to make sure that plants cited by informants are really those used in their daily pharmacopoeia. Mpondo et al., used only the number of citations in the Center and Littoral Regions of Cameroon [32]. Betti et al., showed that, in the Dja biosphere reserve in Cameroon, plants cited at least twice (with at least two citations or by at least two different informants) against the same ailment (spatial common usage), were often recognized in the literature to possess effective chemical compounds for the ailments indicated [18, 21, 33]. In this paper, plant species were selected based on both the large number of citations in recipes in the treatment hemorrhoids (at least five citations), and also on the diversity of citations given by informants from different sites involved in the Ethnobotanical survey. Ilumbe et al. in Congo mentioned Mangifera indica and Alchornea cordifolia as one of the plant species used for the treatment of hemorrhoids [6].

In our study, 48 plants involved in the preparation of 125 recipes were identified. This is similar to results obtained by Ilumbe et al. who found 56 plants in 108 recipes and Dibong et al., who on antihemorrhoidal plants found 60 plants for 48 recipes [6, 20]. This is an indication that with the increase of deforestation, a reduction in the diversity of plant species would not hinder the treatment of hemorrhoidal disease. Healers usually combined two to four plants species in the recipes they give to patients $[6,20]$. This is in contrast with that of N'Guessan et al., who found that amongst the 44 recipes developed to treat malaria, $44(86.27 \%)$ of them were mono-specific recipes [34]. According to them, this preponderance of monospecific recipes is rather advantageous to patients because, in Africa, about $30 \%$ of the lethal cases caused by traditional drugs were due to the use of mixtures. This opinion is far from being shared by the tradipractitioners of Cameroon who usually prepare drugs with at least two to three plants to cure diseases. They use mixtures because not only does each plant species have a specific role to play in the treatment of symptoms of a given disease, but also because some plant species can mitigate the toxic effects of others when they are combined together.

Plant species of the Fabaceae and Euphorbiaceae families were among the most cited to treat hemorrhoidal diseases $[6,20]$. Species of Moraceae and Anacardiaceae families were also of great interest $[35,36]$. Some authors mention that the species of these families are particularly rich in various secondary metabolites, but that they have a low concentration of phenolic compounds [36-40].

Healers used the leaves when they want to use the herbaceous plants species and the barks for ligneous plant species. The presence of secondary metabolites in the leaves may be due to the fact that it is the site of biosynthesis. Ngene et al., indicate that the barks of plant species were the storage site of these metabolites and could contain more of them [41]. Harvesting techniques of plant parts were the same with those described by N'Guessan et al., [34]. However, plant species usually face the problem of poor harvesting techniques because villagers usually harvest the plant species without taking into consideration their vegetative and physiological state and much less about their regeneration capacity $[19,20]$.

Tradi-practitioners indicated that the recipes for the different types of hemorrhoids was the same since it is when internal hemorrhoids is in an advanced stage that they become prolapsed (external hemorrhoids). Drinks and sitting baths are usually forms through which the active ingredient of decoctions made up of barks are administered. On the other hand, suppositories and / or garniture are mostly used when leaves are crushed and mixed with palm kernel oil for hemorrhoidal prolapse [20]. The rectal route (sitting bath, filling, suppository, anal anointing) were the main route for administering medicinal recipes because, scientifically, hemorrhoids are often described as varicosities of the rectal veins and are characterized by a relaxation of the anal sphincter; hence the interest of applying a well-localized treatment. According to tradipractitioners, medicinal plants improved on the symptoms of hemorrhoids in accordance with Roja and Mohammad and Dibong et al., who found that, the mechanisms of action of these plants include antiinflammatory, anti-nociceptive, venotonic and venoprotective activities or even stool softening by absorption of water $[15,20]$.

Results of the preliminary studies on the chemical analysis of the plants of interest showed that these plants were rich in flavonoids, tannins, phenols, saponins, terpenes and coumarins. These results are in accordance with that of Caliskan et al., who indicated that there is a number of anti-hemorrhoidal preparations based on plants in the world besides flavonoids [42]. These preparations contain a saponin derivative such as aescin; a coumarin derivative such as esculoside; terpene derivatives such as menthol, carvacrol; and furthermore plant extracts such as Ruscus aculeatus Linn., Aesculus hippocastanum Linn, Hamamelis virginiana Gronov. ex Linn., Achille millefolium Linn, Chamaemelum nobile Linn., Arnica chamissonis Linn., Mentha xpiperita Linn., Alluim sativum Linn., Quercus Linn., Rubia tinctorum Linn and Ginkgo biloba Linn that are rich in flavonoids, tannins and in volatile compounds. Furthermore, the plants used in the treatment of hemorrhoids contain sap and fibers in abundance. According to tradi-practitioners the villages of the Southern and Eastern Region of Cameroon, would have the role of re-tightening the tissues of damaged organs. These fibers facilitate internal transit, 
thus limiting the risk of diarrhea and constipation. Ligneous species are mostly used for the treatment of hermorroidal diseases which from the ecological point of view seems to be detrimental due to the destructive cultivation of plant parts [20, 30, 43]. However, because of the perennial nature of these species, it is possible to have at least one plant part each season, hence the interest of knowing the total content of active compounds of these plant part.

\section{REFERENCES}

1. Mbolo, M., Walter, S., \& Lejeune. (2002). La collecte et l'analyse des données statistiques sur les produits forestiers non ligneux, Une étude pilote au Cameroun, FOPW/02/.2. Rome.

2. Guedje, N. M., Tadjouteu, F., Dongmo, R. F., Jiofack, R. B. T., Tsabang, N., Fokunang, C. N., \& Fotso, S. (2012). Medecine traditionnelle africaine (MTR) et phytomédicaments : défis et stratégies de développement. Health Sciences Diseases, 12, 25.

3. Boureima, D. (2006). Connaissances, attitudes et pratiques comportementales liées aux hémorroïdes dans le service de chirurgie générale du CHU Gabriel Touré et auprès des thérapeutes traditionnels au Mali, Thèse de Doctorat, Université de Bamako, Mali, 100.

4. Dal Monte, P. P., Tagariello, C., Giordano, P., Cudazzo, E., Shafi, A., Sarago, M., \& Franzini, M. (2007). Transanal haemorrhoidal dearterialisation: nonexcisional surgery for the treatment of haemorrhoidal disease. Techniques in Coloproctology, 11, 333-339.

5. Alonso-Coello, P., Zhou, Q., Martinez-Zapata, M. J., Mills, E., Heels-Ansdell, D., Johanson, J. F., \& Guyatt, G. (2006). Meta-analysis of flavonoids for the treatment of haemorrhoids. British Journal of Surgery, 93, 909-920.

6. Ilumbe, G. B., Van Damme, P., Lukoki, F. L., Joiris, V., Visser, M., \& Lejoly, J. (2014). Contribution à l'étude des plantes médicinales dans le traitement des hémorroïdes par les pygmées Twa et leur voisin Oto de Bikoro, en RDC. Congo Sciences, 2, 46-54.

7. Kaidar-Person, O., Person, B., \& Wexner, S. D. (2007). Hemorrhoidal desease: a comprehensive review. Journal of the American College of Surgeons, 204, 102-117.

8. Ganz Robert, G. (2013). The Evaluation of Treatment of Hemorrhoids: A Guide for the Gastroenterologist. Clinical Gastroenterology and Hepatology, 11, 593-603.

9. Haas, P. A., Haas, G. P., Schmaltz, S., \& Fox, T. A. (1983). The prevalence of hemorrhoids. Diseases of the Colon and Rectum, 26, 435-439.

10. Diallo, G., Sissoko, F., Maiga, M. Y., Traore, A. K. D., Ongoiba, N., Dembele, M., Doumbia, D., Coulibaly, Y., Diallo, A., Mariko, H., \& Koumara, A. K. (2003). La maladie hémorroïdaire dans le service de chirurgie de l'hôpital du point G. Mali médical, 1(2), 9-11.

11. Senéjoux, A. (2010). Hémorroïdes. EC (Elsevier Masson SAS, Paris), Gastroentérologie, 9-086-A10, 12.

12. Ankouane Andoulo, F., Kowo, M., Ngo Nonga, B., Djapa, R., Tagni-Sartre, M., Njoya, O., Ngu Blackett, K., Biwolé Sida, M., \& Ndjitoyap Ndam, E. C. (2013). Indications, résultats et rendement de la coloscopie dans un environnement économique défavorable : Cas du Cameroun. Health Sciences and Diseases, 14, 1-6.

13. Lohsiriwat, V. (2012). Hemorrhoids: From basic pathophysiology to clinical management. World Journal of Gastroenterology, 18, 2009-2017.

14. Higuero, T. (2014). Traitement de la pathologie hémorroïdaire: les nouvelles recommandations. Post'u, 1-11.

15. Roja, R., \& Mohammad, A. (2013). Evidencebased Reviewd of medicinal plants used for treatment of hemorrhoids. International Journal of Pharmacology, 9, 1-11.

16. Biaye, M. (2002). Action pharmacologique des tanins, Thèse de Doctorat en Pharmacie, Université Cheikh Anta Diop de Dakar, Sénégal, 53.

17. Hennebelle, T., Sahpaz, S., Skaltsounis, A. L., \& Bailleul, F. (2007). Phenolic compounds and diterpenoids from Marrubium peregrinum. Biochemical Systematics and Ecology, 35, 624626.

18. Kabuye, C. (2000). Généralités sur la recherche économique et les Produits Forestiers Non ligneux. Recherches actuelles et perspectives pour la conservation et le développement. FAO. Rome, 117- 121.

19. Priso, R. J., Nnanga, J. F., Etame, J., Din, N., \& Amougou, A. (2011). Les produits forestiers non ligneux d'origine végétale : valeur importance dans quelques marchés de la région du littoralCameroun. Journal of Applied Biosciences, 40, 2715-2726.

20. Dibong, S. D., Mvogo Ottou, P. B., Vandi, D., Ndjib, R. C., Monkam Tchamaha, F., \& Mpondo Mpondo, E. (2015). Ethnobotanique des plantes médicinales anti hémorroïdaires des marchés et villages du Centre et du Littoral Cameroun. Journal of Applied Biosciences, 96, 9072-9093.

21. Betti, J. L., Yongo, O. D., Obiang Mbomio, D., Iponga, D. M., \& Ngoye, A. (2013). An Ethnobotanical and Floristical Study of Medicinal Plants Among the Baka Pygmies in the Periphery of the Ipassa- Biosphere Reserve, Gabon. European Journal of Medicinal Plants, 3, 174205.

22. Schnell, R. (1960). Techniques d'herborisation et de conservation des plantes dans les pays tropicaux. Journal d'Agriculture Tropicale et de Botanique Appliquée, 7, 1-48. 
23. Andrade-Cetto, A. \& Heinrich, M. (2011). From the field into the lab: useful approaches to selecting species based on local knowledge. Front Pharmacology, 2, $20 \mathrm{p}$.

24. [24] Ampa, R., Diatewa, M., Ahombo, G., Dimo, T., Nguimbi, E., \& Abena, A.A. (2014). Effet de l'extrait hydro-éthanolique des feuilles de Trilepisium madagascariense Leeuwenberg D.C. (Moraceae) contre le stress oxydant associé au diabète sucré chez le rat. Afrique Science, 10, 278287.

25. Kouwelton Koné, P. F. O., Soro, Y. \& Sorho, S. (2017). Détermination des paramètres influençant le rendement d'extraction hydro-alcoolique des métabolites secondaires de Alchornea cordifolia (Euphorbiaceae) et Tridax procumbens Linn. (Asteraceae). Journal de la Société OuestAfricaine de Chimie, 44, 15-22.

26. Sumitra, C., Jigna, P., \& Nehal, K. (2006). Evaluation of antibacterial activity and phytochemical analysis of Bauhinia variegate $\mathrm{L}$. bark. African Journal of Biomedical Research, 9, 53-56.

27. [27] Teke, G.N., Kuiate, J-R., Kueté, V., Teponno, R.B., Tapondjou, L.A., Tane, P., Giacinti, G., \& Vilarem, G. (2011). Bio-guided isolation of potential antimicrobial and antioxidant agents from the stem bark of Trilepisium madagascariense. South African Journal of Botany, 77, 319-327.

28. Ndjib, R. C., Dibong, S. D., Mvogo Ottou, P. B., Nyegue, M. A. \& Eto, B. (2017). Ethnobotanical Study of Medicinal Plants Used in the Treatment of Vaginal Infections in Four Towns in Cameroon. Saudi Journal of Life Science, 2, 366-373.

29. Ribière, S. (2012). Pathologie hémorroïdaire. IHP, des hépato-gastro 33.

30. Betti, J. L. (2002). Medicinal plants sold in Yaoundé markets, Cameroon. African study Monographs, 23, 47-64.

31. Allabi, A. C., Busiac, K., Ekanmiana, V., \& Bakiono, F. (2011). The use of medicinal plants in self-care in the Agonlin region of Benin. Journal of Ethnopharmacology, 133, 234-243.

32. Mpondo Mpondo, E., Vandi, D., Ngouondjou Foze, T., Mvogo Ottou, P. B., Embolo, E. E., \& Dibong, S. D. (2017). Contribution des populations des villages du centre Cameroun au traitement traditionnel des affections des voies respiratoires. Journal of Animal and Plant Sciences, 32, 5223-5242.

33. Koné, D. (2009). Enquête ethnobotanique de six plantes médicinales maliennes - extraction, identification d'alcaloïdes - caractérisation, quantification de polyphénols : étude de leur activité antioxydante, Thèse de Doctorat Université de Bamako, Mali, 157.

34. N'Guessan, K., Tra Bi, F. H., \& Koné, M. W. (2009). Étude ethnopharmacologique de plantes antipaludiques utilisées en médecine traditionnelle chez les Abbey et Krobou d'Agboville (Côte d'Ivoire). Ethnopharmacologia, 44, 42-50.

35. Kibungu Kembelo, A. O. (2004). Quelques plantes médicinales du Bas-Congo et leurs usages. Revue des plantes médicinales existantes en République Démocratique du Congo, province du Bas-Congo. 177.

36. Adomou, A. C., Yedomonhan, H., Djossa, B., Legba, S. I., Oumorou, M., \& Akoegninou, A., (2012). Étude ethnobotanique des plantes médicinales vendues dans le marché d'AbomeyCalavi au Bénin. International Journal of Biology and Chemical Science, 6, 745-772.

37. Sereme, A., Millogo-rasolodimby, J., Guinko, S., \& Nacro, M. (2008). Propriétés thérapeutiques des plantes à tanins du Burkina Faso. Pharmacopée et Médecine traditionnelle Africaines, 15, 41-49.

38. Bruneton, J. (2009). Pharmacognosie, phytochimie, plantes médicinales, 4e édition, Ed. Tec \& Doc, Paris, 1269.

39. Ambe, A. S. A., Ouattara, D., Tiebre, M. S., Vroh, B. T. A., Zirihi, G. N., \& N'Guessan, K. E., (2015). Diversité des plantes médicinales utilisées dans le traitement traditionnel de la diarrhée sur les marchés d'Abidjan (Côte d'Ivoire). Journal of Animal and Plant Sciences, 26, 4081-4096.

40. Nnanga Nga, E., Yinyang, J., Baran Bidias, E., Etame-Loe, G., \& Dibong, S. D. (2017). Étude phytochimique et pharmacologique d'Alchornea cordifolia (Schum. \& Thonn.) Mull. Arg. et de Mangifera indica dans le traitement traditionnel de la maladie hémorroïdaire. Journal of Applied Biosciences, 109, 10649-10661.

41. Ngene, J. P., Ngoule, C. C., Pouka Kidik, C. M., Mvogo Ottou, P. B., Ndjib, R. C., Dibong, S. D., \& Mpondo Mpondo, E. (2015). Importance dans la pharmacopée traditionnelle des plantes à flavonoïdes vendues dans les marchés de Douala est (Cameroun). Journal of Applied Biosciences, 88, 8194-8210.

42. Caliskan, U. K., Aka, C., \& Goker, O. Z. M. (2017). Plants Used in Anatolian Traditional Medicine for the Treatment of Hemorrhoid. Records of Natural Products, 11, 235-250.

43. Kidik Pouka, M. C., Ngene, J. P., Ngoule, C. C., Mvogo Ottou, P. B., Ndjib, R. C., Dibong, S. D., \& Mpondo Mpondo, E. (2015). Caractérisation des plantes médicinales à flavonoïdes des marchés de Douala (Cameroun). International Journal of Biological and Chemical Sciences, 9, 1494-1516. 